\title{
The Effect of Service Quality and Profit Sharing on Customers' Satisfaction of Mudharabah Savings at PT. Bank Syariah Mandiri Gorontalo Branch Office, Indonesia
}

\author{
Adelia Arkani $^{1}$, (D) Muhibbuddin Muhibbuddin ${ }^{2 *}$ \\ ${ }^{1}$ Bank Syariah Indonesia Gorontalo, Indonesia \\ ${ }^{2}$ Institut Agama Islam Negeri Sultan Amai Gorontalo, Indonesia \\ ${ }^{*}$ Corresponding Email: muhibiain75@gmail.com
}

Keywords:

Service Quality, Profit Sharing, Customers Satisfaction
Kata Kunci:

Kualitas Layanan, Bagi Hasil, Kepuasan

Nasabah

\begin{abstract}
This research aims to determine and test the effect of service quality and profit sharing on customesrs'satisfaction of Mudharabah savings in Gorontalo branch office. This is a quantitative research. The research populations were customers at PT. Bank Syariah Mandiri Gorontalo Branch Office. The sample used in this research amounted to 90 customers. Primary datawerecollected through questionnaire whichwasthen processed using IBM SPSS 25 application. The data analysis method used simple regression analysis. The results indicate that there is positive and significant influence of service quality and profit sharing on Customers' Satisfaction of Mudharabah savings at PT. Bank Syariah Mandiri Gorontalo Branch Office with value of 1,178 in its significance of 0.242 , and the rest is affected by other factors out of this research discussion.
\end{abstract}

\section{INTRODUCTION}

The concept of service quality has become a very dominant factor in the success of organizations, both profit and non-profit, because if customers or consumers receive good service quality as expected, they will be satisfied, trust and have commitment to remain

Issue:

Hou To Cite: 
Arkani, A., \& Muhibbuddin, M. | The Effect of Service Quality_

ascustomers in a particular organization. Customers who feel satisfied, believe and are committed to certain good/servicewill easily form their intention to repurchase and tend to be more frequent in purchasing the goods/service, and more loyal to that certain good/service. Service quality can be defined as an effort to fulfill consumer's needs and desires as well as delivery accuracy in balancing consumer's expectations.(Tjiptono Fandy, 2012).

Tjiptono Fandy (2012) also argued that if a customer expects a certain level of service, and feels that the service he receives is in accordance with his expectations, then the customer can be said to be satisfied. Conversely, if the quality of service he receives is lower than the expected quality, then the customer is said to be dissatisfied so that he will not believe in the service or in other word is disappointed.

In providing services, a bank must at least meet 5 service quality dimensionto create loyal customers, namely tangibility, reliability, responsiveness, assurance, empathy. Tangibility can be seen from physical facilities, equipments, employees, and means of communication. Reliability is shown on the ability to provide the promised service immediately and satisfactorily. Responsiveness represents the desire of staff to help customers and provide responsive service. Assurance includes ability, courtesy and trustworthiness of staff, free from harm, risk or doubt. (FandyTjiptono and Anastasia Diana,2012) Empathy includes the ease of creating good communication, and understanding the needs of customers.

Service and product performance are highly considered by consumers in order to provide satisfaction. Consumers can feel and conclude by giving expectations and assumptions. If the service and product performance do not match expectations, the consumersare dissatisfied. On the other hand, if the service and product performance meet expectations, the consumersare satisfied. If the service and product performance exceed expectations, then the customersare very satisfied. In determining level of satisfaction, a customer often looks at extra value of a product or service performance he received from a purchase process. The amount of extra value given by a product (or service) to the customer is the answer to why the customer makes his decision. Customers are basically looking for the greatest value that a product (service) provides (Danang Sunyoto dan Fathonah Eka Susanti, 2015).

Raihanah Daulay (2014) in his research journal stated that in addition to service issue, there are also problems in terms of profit sharing of savings products perceived by customers. The customers are impressed by the level of profit or benefit they will get from Mudharabah saving products. The customers tend to prefer a larger profit sharing distribution by well known Islamic bank with many customers.

Customers' satisfaction bringsmore benefits to thebankingcompanies. By achieving high level of customers' satisfaction can prevent customer turnover, reduce customers' sensitivity to prices, reduce marketing failure costs, reduce operating costs caused by increasing number of customers, increase advertising effectiveness, and improve business reputation (Dwi Aryani dan Febrina Rosinta, 2011).

This satisfaction is important to measure so that companies, in this case Islamic banks, can find out what attributes of product bring satisfaction to customers. Information on customers' perceptions will assist Islamic banks in providing best service to their customers, thus the customers become satisfied and can increase third party funds at Islamic banks.

Problem Statements

1. Do service quality and profit sharing partially affect customers' satisfaction of Mudharabah saving at Bank Syariah Mandiri Gorontalo Branch Office?

2. Do service quality and profit sharing have simultaneous effect on customers' satisfaction with Mudharabah savings at Bank Syariah Mandiri Gorontalo Branch Office? 
Arkani, A., \& Muhibbuddin, M. | The Effect of Service Quality_

\section{LITERATURE REVIEW}

\section{Service Quality}

Mulyo Budi Setiawan dan Ukudi (2007) in his economic journal defines service quality as a concept that accurately represents core of service performance which is comparison to reliability (excellence) in service encounters carried out by consumers. In addition, according to Lovelock et.al (2010) service quality is the level of excellence expected and control over advantages to meet customers' expectations.

If the service received or perceived by the customer is in line with their expectations, then the service quality is perceived to be good and satisfying. In contrast, if the service fails to meet the customers' expectation, then the service is assumed to be poor or dissatisfying.

Pasuraman describes service quality as a concept that accurately represents core of service performance that is comparison to reliability (excellence) in service encounters carried out by consumers. (Setiawan2007). There are 5 dimensions of service quality according to Setiawan (2007), namely: Tangibles, Reliability, Responsiveness, Assurance and Empathy.

\section{Profit Sharing}

According to Al-Qardhawi in Daulay (2014) profit sharing is when two parties agree to share profits in accordance with the acknowledged agreement where the profit sharing requires cooperation between owner of the capital and the business/work for mutual benefit of both parties. As a consequence of cooperation is to bear risks, both profit and loss. If the profit earned is large, the funds providers and workers share it together according to the previous agreement and if the loss is encountered, it must be shared as well.

There are 2 (two) types of profit-sharing principles used in Mudharabah savings products at Islamic Banks, namely profit sharing and revenue sharing. Quoted from Wordpress profit sharing according to Indonesian etymology is profit sharing. In the economic dictionary, it is defined as profit sharing. Profit is the difference that arises when total revenue of a company is greater than its total cost. Meanwhile, revenue sharing comes from English which consists of two words, namely, revenue which means result or income. Sharing is the verb form of share which means to share. Thus, revenue sharing means the sharing of results or income.

Every purchase of goods or service products of consumer is affected by level of profit or benefits from these products. The profit level that will be obtained by consumers on bank services, especially Islamic banks is profit sharing. There are 4 dimensions of profit sharing, they are percentage, profit \& loss sharing, guarantees, and amount of ratio determination. (Karim, 2007).

\section{Mudharabah Savings}

Soemitra (2014) in his book explains that savings are deposits based on Wadi'ah contracts or investment funds based on Mudharabah contracts or other contracts that do not cross sharia principles and their withdrawals can only be made according to certain agreed terms and conditions, but cannot be withdrawn by cheque, transfrer, and/or other equivalent tools.

Sharia savings principles are regulated in the National Sharia Council Fatwa No. 02/DSN-MUI/VI/2000 concerning Savings. There are two types of savings, namely savings that are not justified by sharia which is based on interest calculations and justified savings by sharia which is based on the principles of Wadi'ah and Mudharabah. (Soemitra, 2014). Yaya (2014) 
Arkani, A., \& Muhibbuddin, M. | The Effect of Service Quality_

stated that the difference between Wadi'ah and Mudharabah savings lies in three aspects, namely the nature of funds, incentives, and refunds.

\section{Customers' Satisfaction}

Satisfaction, according to Kotler and Keller, is expressed as the level of feeling when a person states comparison results of a product/service performance of what he received and he expected. (Ratnasaridkk, 2011). According to Schnaars, the purpose of a business is to make customers feel satisfied. Superior and consistent service quality can foster customers' satisfaction and will provide various benefits. (Rustika Atmawati dan Wahyuddin, 2004)

Sofiyanto, et.al (2010) elaborates that customer's satisfaction is the performance of an item that at least equal to what is expected. Customers' satisfaction can be defined as an evaluation that provides results where the perceived experience is at least as good or as expected.

According to Rangkuti in Atmawati (2004) customers' satisfaction is as the customers' responses to discrepancy between previous level of importance and actual performance felt after usage. Factors that might influence customers' satisfaction are: customers' value, response and perception.

Kotler (2003) mentioned several methods that can be used by every company to measure and monitor the satisfaction of its customers and those of competing companies. There are 4 methods to assess customers' satisfaction, namely complaint and suggestion system, customers' satisfaction surveys, stealth shopping and lost customer analysis.

\section{METHODOLOGY}

This research design used multiple linear regression method which took place at PT. Bank Syariah Mandiri Gorontalo Branch Office. The sampling technique in this research was accidental sampling which was then determined using Slovin Umar formula (2008) with significance tolerance level of 5\%. Therefore, that of 865 respondents, 90 samples were selected. In preparing the measurement scale, the Likert scale method was used where each respondent was asked for his opinion on a statement with a rating scale from 1 to 5 Sugiyono (2007). The data analysis used quantitative methods that run processes of validity test, reliability test, classical assumption test (multicollinearity test, heteroscedasticity test, and normality test), regression analysis, and hypothesis test ( $\mathrm{t}$ test and $\mathrm{F}$ test) and model accuracy test or goodness of fit of a model, namely coefficient of determination $\left(\mathrm{R}^{2}\right)$.

Ukudi, et.al (2007) identified at least five kinds of service quality indicators, they are: indicators of tangible, reliability, responsiveness, empathy, and assurance. There are four indicators for profit sharing, namely percentage, profit and loss sharing, guarantees, and amount of ratio determination. Meanwhile, satisfaction includes customers' responses and perceptions. Based on the explanations above, it can be formulated that models and hypotheses in this research are:

Figure: Research Framework Model

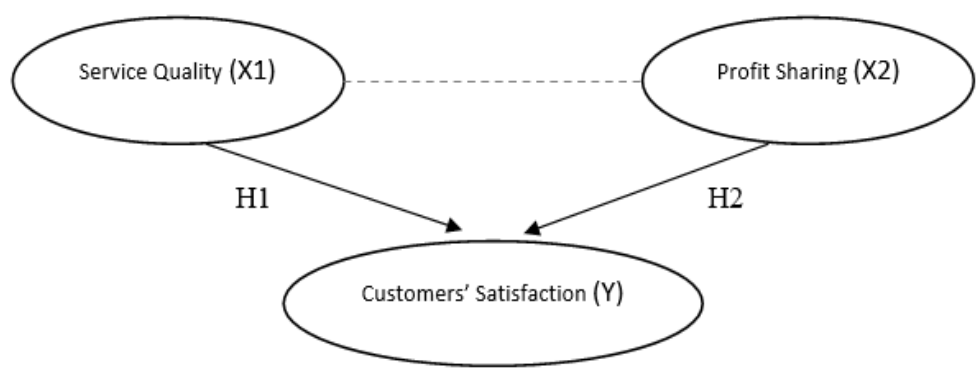


Arkani, A., \& Muhibbuddin, M. | The Effect of Service Quality_

\section{RESULT AND DISCUSSION}

\section{Result}

This research has service quality and profit sharing as independent variables, and profit sharing variable as dependent variable. Detail influence between variables will be described as follows:

\section{Simultaneous hypothesis testing (F test)}

The $\mathrm{F}$ test was used to determine the effect of the independent variables contained in the model together on the dependent variable, namely the effect of service quality and profit sharing on customers' satisfaction. The results of the F test test can be seen in the following table:

Table 1: ANOVA

\begin{tabular}{clccccc}
\hline & \multicolumn{1}{c}{$\begin{array}{c}\text { Model } \\
\text { Sum of }\end{array}$} & Sum of Squares & Df & Mean Square & F & Sig. \\
\hline \multirow{4}{*}{1} & Regression & 527,313 & 2 & 263,656 & 63,932 &, $000 \mathrm{~b}$ \\
\cline { 3 - 5 } & Residual & 358,787 & 87 & 4,124 & & \\
& Total & 886,100 & 89 & & & \\
\hline
\end{tabular}

a. Dependent Variable: Customers' satisfaction

b. Predictors: (Constant), profit sharing, service quality

The table above shows that the $\mathrm{F}_{\text {count }}$ value is 63,932 with a significance value of 0.000 . Because the significance level is less than 0.05 , then $\mathrm{Ha}_{3}$ is accepted, thus it can be said that the quality of service and profit sharing simultaneously have significant effect on customers' satisfaction. This indicates that the regression model can be used to predict customers' satisfaction.

\section{Partial determination coefficient test results ( $t$ test)}

Statistical $t$ test was used to find out the effect of independent variables (service quality and profit sharing) simultaneously or partially on dependent variable (customers' satisfaction). Further details can be seen in the following table:

Table 2: Coefficient

\begin{tabular}{llccccc}
\hline \multirow{2}{*}{ Model } & \multicolumn{2}{c}{$\begin{array}{c}\text { Unstandarized } \\
\text { Coefficients }\end{array}$} & $\begin{array}{c}\text { Standarized } \\
\text { Coefficients }\end{array}$ & \multirow{2}{*}{ t } & Sig. \\
\cline { 2 - 5 } & \multicolumn{1}{c}{ B } & Std. Error & Beta & & \\
\hline \multirow{2}{*}{1} & (Constant) & 2,911 & 2,470 & & 1,178 &, 242 \\
& Kualitas Layanan &, 192 &, 039 &, 403 & 4,885 &, 000 \\
& Bagi Hasil &, 366 &, 064 &, 470 & 5,701 &, 000 \\
\hline
\end{tabular}

a. Dependent Variable: Customers' satisfaction $\mathrm{t}_{\text {tabel }}=\mathrm{t}(\alpha / 2 ; \mathrm{n}-\mathrm{k}-1=\mathrm{t}(0.05 / 2 ; 90-2-1)=(0,025 ; 87)=1,98761$ 
Arkani, A., \& Muhibbuddin, M. $\mid$ The Effect of Service Quality_

1. Testing Hypothesis 1 for Service Quality Variable

From the table above, it is obtained that $\mathrm{t}_{\text {coun }}$ is 4.885 and the value of $\mathrm{t}_{\text {table }}$ is known to be 1.98761 . By comparing $t_{\text {count }}$ and $t_{\text {table, }}$, where $4.885<1.98761$, it is found that $t_{\text {count }}>t_{\text {table. }}$ The result obtained the comparison of sig. with a significance level of $5 \%=$ $0.000<0.05$, it can be concluded that $\mathrm{H}_{1}$ is accepted; meaning that service quality partially has positive and significant effect on customers' satisfaction.

2. Testing Hypothesis 2 for Profit Sharing Variable

From the table above, it is obtained that $t_{\text {count }}$ is 5.701 and the value of $t_{\text {table }}$ is known to be 1.98761. By comparing $\mathrm{t}_{\text {count }}$ and $\mathrm{t}_{\text {table, }}$, where $5.701<1.98761$, then it is found taht $t_{\text {count }}>t_{\text {table. }}$ The result obtained the comparison of sig. with a significance level of $5 \%=$ $0.000<0.05$, it can be concluded that $\mathrm{H}_{2}$ is accepted which means the profit sharing partially has significant positive influence on customers' satisfaction.

\section{The results of coefficient determination test simultaneously}

To determine the influence of Islamic religiosity and Islamic work ethic on job satisfaction variable simultaneously, the results of the calculations are shown in the table below, especially the following R Square numbers:

Table 3: Model Summary

\begin{tabular}{c|c|c|c|c}
\hline Model & R & R Square & Adjusted R Square & $\begin{array}{c}\text { Std. Error of the } \\
\text { Estimate }\end{array}$ \\
\hline 1 &, $771^{\mathrm{a}}$ &, 595 &, 586 & 2,031 \\
\hline
\end{tabular}

a. Predictors: (Constant), profit sharing, service quality

Table above indicated that the value of $R$ Square is 0.595 or $59.5 \%$. This means that service quality and profit sharing variables can explain $59.5 \%$ of customers' satisfaction variable. The remaining $40.5 \%(100 \%-59.5 \%)$ is determined by other variables that are not included or discussed in this research.

\section{Discussion}

\section{The Effect of Service Quality on Customers' Satisfaction}

From the results of data processing in the previous chapter, it can be concluded that H1 is accepted, this means that service quality partially has positive and significant effect on customers' satisfaction. The result of this research supports the research result conducted by Raihanah Daulay (2014) that service quality has positive and significant effect on saving decisions of customers. Pasuraman defines service quality as a concept that accurately represents the core of service performance, namely the comparison to reliability (excellence) in service encounters made by consumers.

The result analysis above indicates that the service quality variable has an effect on customers' satisfaction at PT Bank Syariah Mandiri Gorontalo Branch Office. This is probably due to the quality of services provided by Bank Syariah Mandiri Gorontalo Branch Office which is able to meet the needs and desires of the customers, for instance, theuse of latest equipment 
Arkani, A., \& Muhibbuddin, M. | The Effect of Service Quality_

and technology in providing services to the customers, visually attractive physical facilities, neat and professional looking employees, on time service, polite communication of the bank employees with the customers, and other services.

\section{The Effect of Profit Sharing on Customers' Satisfaction}

From the result of data process in the previous chapter, it can be said that $\mathrm{H}_{2}$ is accepted, meaning that the profit sharing partially has positive and significant influence on customers' satisfaction. The result of this research supports the result of research conducted by Kharisma Mahkota Perdana and Agus Prayitno (2014) in which profit sharing has positive and significant effect on customers' satisfaction at Bank Victoria Syariah in Brebes.

According to Al-Qardhawi in Daulay profit sharing is where two parties share profits in accordance with the agreed agreement, in which the profit sharing requires the cooperation of the owner of the capital with the business/work for the mutual benefit of both parties. As a consequence of cooperation, both parties bear the risk, either profit or loss. If the profit obtained is large, the provider of funds and workers share it in accordance with the previous agreement and if the loss is occurred, it must be shared as well.

The result of the analysis above shows that the profit sharing variable has an effect on customers' satisfaction at PT Bank Syariah Mandiri Gorontalo Branch Office. This is probably because of the profit sharing provided by Bank Syariah Mandiri Gorontalo Branch Office is able to fulfill the customers' desires such as the bank informsthe customers that the profit sharing ratio is calculated based on percentage, that the profit sharing ratio is not in accordance with the portion of the capital deposit but based on an agreement, and also the bank notifies the current profit sharing ratio.Service Quality and Profit Sharing on Customers' Satisfaction

Based on the processed data in the previous chapter, the significance level is less than 0.05 , thus $\mathrm{H}_{3}$ is accepted. In other words, service quality and profit sharing simultaneously have significant effect on the customers' satisfaction. This indicates that the regression model can be used to predict the customers' satisfaction.

Therefore, in PT. Bank Syariah Mandiri Gorontalo Branch Office, the quality of service can meet all the needs and desires of the customers, and the perceived profit sharing is in accordance with the customers' expectations, thus it will increase the customers' satisfaction on the Bank Syariah Mandiri Gorontalo Branch Office.

\section{CONCLUSIONS}

This research found empirical data on the effect of service quality and profit sharing on customers' satisfaction ofMudharabah savings at PT. Bank Syariah Mandiri Gorontalo Branch Office. Respondents in this research were 90 customers of PT. Bank Syariah Mandiri Gorontalo Branch Office.

Based on the data analysis in the previous chapter, it can be concluded that the higher the level of service quality and profit sharing provided by the bank, the higher the level of the customers' satisfaction on PT. Bank Syariah Mandiri Gorontalo Branch Office. This can be seen from the results of research using multiple linear regression analysis as follows:

1. Based on the results of multiple linear regression through the t-test of service quality and profit sharing variables, it shows a significant effect on the customers' satisfaction ofMudharabah savings at PT. Bank Syariah Mandiri Gorontalo Branch Office.

2. Based on the results of multiple linear regression test through the $F$ test, the service quality and profit sharing variables have a significant effect on the customers' satisfactionofMudharabah savings at PT. Bank Syariah Mandiri Gorontalo Branch Office. 
Arkani, A., \& Muhibbuddin, M. | The Effect of Service Quality_

3. The independent variable that has dominanteffect on the dependent variable is profit sharing. This statement can be proven by the value of the regression coefficient (B) of 0.366 which is greater than the value of the regression coefficient of the other variable, namely the service quality in the value of 0.192 .

\section{REFERENCES}

Al-Qardhawi, Y. (2001). Bunga Bank Haram. Alih bahasa Setiawan Budi Utomo. Cetakan Pertama. Jakarta: Akbar.

Aryani, D., \& Rosinta, F. (2011). Pengaruh kualitas layanan terhadap kepuasan pelanggan dalam membentuk loyalitas pelanggan. BISNIS \& BIROKRASI: Jurnal Ilmu Administrasi dan Organisasi, 17(2).

Atmawati, R., \& Wahyuddin, M. (2004). Analisis pengaruh kualitas pelayanan terhadap kepuasan konsumen pada Matahari Departement Store di Solo Grand Mall. Jurnal Ekonomi Manajemen Sumber Daya, 5(1).

Daulay, R. (2014). Pengaruh Kualitas Pelayanan dan Bagi Hasil Terhadap Keputusan Menabung Nasabah Pada Bank Mandiri Syariah di Kota Medan. Jurnal Riset Akuntasi dan Bisnis

Fandy, T., \& Diana, A. (2001). Total Quality Management Edisi Revisi. Yogyakarta: Andi.

https://jejakimawan.wordpress.com/ diakses pada tanggal 17 Januari 2020.

Husein, U. (2008). Metode Penelitian Untuk Skripsi dan Tesis Bisnis. Jakarta. PT Rajagrafindo Persada.

Karim, A. (2007). Analisis Fiqih dan Keuangan. Jakarta: PT. Raja Grafindo Persada.

Kasiram, M. (2008). Metode Penelitian Kuantitatif - Kualitatif. Malang: UIN Malang Press.

Lovelock, C., Wirtz, J., \& Mussry, J. (2010). Pemasaran Jasa. Jakarta: Erlangga.

Ratnasari, R. T., \& Aksa, M. H. (2011). Manajemen Pemasaran Jasa. Bogor: Ghalia Indonesia.

Ruslan, R. (2004). Metode Penelitian Public Relations dan Komunikasi, Jakarta: PT. Raja Grafindo Persada.

Santoso, S. (2000). Buku Latihan SPSS Statistik Parametrik. Jakarta: PT. Elek Media Komputindo.

Setiadi, N. J. (2010). Perilaku Konsumen: Perspektif Kotemporer Pada Motif, Tujuan, dan Keinginan Konsumen. Edisi Revisi. Cet. 4. Jakarta: Kencana Prenada Media Group.

Setiawan, M. B., \& Ukudi. (2007). Pengaruh Kualitas Layanan, Kepercayaan dan Komitmen Terhadap Loyalitas Nasabah Studi Pada PD. BPR Bank Pasar Kendal. Jurnal Bisnis dan Ekonomi. 
Arkani, A., \& Muhibbuddin, M. | The Effect of Service Quality_

Soemitra, A. (2014). Bank dan Lembaga Keuangan Syariah. Jakarta: Kencana Prenadamedia Group.

Sofiyanto, I., Fathoni, A., \& Haryono, A. T. (2016). Pengaruh Lokasi, Tingkat Suku Bunga, Kualitas Pelayanan Terhadap Kepuasan Nasabah Kredit Pemilikan Rumah (Studi Empiris Pada PT. Bank Tabungan Negara (Persero) Cabang Semarang). Journal of Management, 2(2).

Sugiyono. (2001). Metode Penelitian. Bandung: Alfabeta.

Sunyoto, D., \& Susanti, F. E. (2015). Manajemen Pemasaran Jasa. Yogyakarta: CAPS.

Tjiptono, F. (2012). Manajemen Jasa. Yogyakarta: Andi offset.

Yaya, R. (2014). Akuntansi Perbankan Syariah: Teori dan Praktek Kontemporer Berdasarkan PAPSI 2013. Edisi 2. Jakarta: Salemba Empat.

\section{Copyright Holder:}

(C) Arkani, A., \& Muhibbuddin, M. (2021)

First Publication Right:

Tala'a - Journal of Islamic Finance

Department of Sharia Financial Management IAIN Sultan Amai Gorontalo, Indonesia 